\title{
Hubungan Inisiasi Menyusu Dini dengan Kadar Oksitosin dan Involusi Uteri 2 Jam Post Partum di Klinik Bersalin Swasta Kabupaten Padang Pariaman Tahun 2014
}

\author{
Fatmi Nirmala Sari ${ }^{1}$, Eryati Darwin ${ }^{2}$, Emi Nurjasmi ${ }^{3}$
}

\begin{abstract}
Abstrak
Angka Kematian Ibu (AKI) merupakan salah satu masalah kesehatan dunia. Penyebab AKI terbanyak adalah perdarahan. Inisiasi Menyusu Dini (IMD) merupakan titik awal yang penting untuk menyusui dan membantu merangsang produksi hormon oksitosin yang berperan dalam kontraksi uterus setelah melahirkan, sehingga akan membantu mengurangi pendarahan. Tujuan penelitian ini adalah menentukan hubungan IMD dengan kadar oksitosin dan involusi uteri 2 jam post partum. Jenis penelitian ini adalah observasional dengan pendekatan kohort. Penelitian ini dilaksanakan \pm 3 bulan dengan jumlah subjek 36 orang. Pengolahan data dilakukan dengan komputerisasi. Data disajikan dalam bentuk distribusi frekuensi dan selanjutnya dilakukan independent $t$-test untuk mengetahui hubungan kedua variabel. Hasil penelitian didapatkan rerata kadar oksitosin ibu postpartum yang berhasil IMD adalah $58.47 \pm 1.19 \mathrm{pg} / \mathrm{ml}$ dan rerata tinggi fundus uteri ibu 2 jam postpartum yang berhasil IMD adalah $11.80 \pm$ $0.73 \mathrm{~cm}$. Hasil uji statistik didapatkan nilai $(p<0,05)$. Kesimpulan penelitian yaitu terdapat hubungan yang bermakna antara IMD dengan kadar oksitosin dan involusi uteri 2 jam postpartum. Keberhasilan Inisiasi menyusu dini akan sangat berdampak positif bagi ibu postpartum.
\end{abstract}

Kata kunci: IMD, kadar oksitosin, involusi uteri 2 jam postpartum

\begin{abstract}
Maternal Mortality Rate (MMR) is one of the world's health problems. The main cause of MMR is bleeding. Early Breastfeeding (EBF) is an important starting point for breastfeeding and also stimulate the production of the hormone oxytocin which plays a role in the contraction of the uterus after childbirth, so itt will help to reduce bleeding. The objective of this study was to determine the relationship of EBF with levels of oxytocin and uterine involution 2 hours post partum. This research was observational cohort study. This research was conducted \pm 3 months to 36 subjects. Data processing was performed with computerized. Data presented in the form of frequency distribution and then performed an independent $t$-test to determine the relationship between two variables. The results showed mean levels of oxytocin postpartum who successfully EBF was $58.47 \pm 1.19 \mathrm{pg} / \mathrm{ml}$ and the mean of height fundus 2 hours postpartum who successfully EBF was $11.80 \pm 0.73 \mathrm{~cm}$. Statistical test results obtained value $(p<0.05)$. There is a significant correlation between the EBF levels of oxytocin and uterine involution 2 hours postpartum. The success of early breastfeeding initiation will have a positive impact for postpartum mothers.
\end{abstract}

Keywords: EBF, levels of oxytocin, uterine involution 2 hours postpartum

Affiliasi penulis: 1. Program Studi S2 Magister Kebidanan FK UNAND (Fakultas Kedokteran Universitas Andalas Padang), 2. Bagian Histologi FK UNAND 3. Ikatan Bidan Indonesia, Jakarta. Korespondensi: Fatmi Nirmala Sari,

email: fatmi.nirmalasari@ymail.com, Telp: 082173020200

\section{PENDAHULUAN}

Proses pemulihan organ reproduksi pada masa nifas (involusi) merupakan hal yang sangat penting bagi ibu setelah melahirkan. Proses involusi merupakan landasan yang penting bagi bidan dalam melakukan pemantauan proses fisiologis kembalinya 
uterus ke kondisi saat tidak hamil. Hal ini karena setelah kosong, uterus tetap mempertahankan struktur muskularnya dan tampak seperti kosong. Rongga uterus ini tetap berpotensi untuk membesar lagi, meskipun saat ini mengalami penurunan ukuran secara nyata. Hal inilah yang mendasari kebutuhan untuk melakukan observasi tinggi fundus uteri. ${ }^{1}$

Ibu yang melakukan Inisiasi Menyusu Dini (IMD) akan mempercepat involusi uterus karena pengaruh hormon oksitosin ditandai dengan rasa mules karena rahim yang berkontraksi. Peningkatan pemberian ASI perlu dilakukan dalam upaya peningkatan kesehatan bagi bayi dan ibu. Upaya tersebut dapat dilakukan antara lain dengan cara pemberian ASI secara dini atau yang dikenal dengan $\mathrm{IMD}^{2}$

IMD merupakan titik awal yang penting untuk proses menyusui, serta untuk membantu mempercepat pengembalian rahim ke bentuk semula dan mengurangi perdarahan setelah kelahiran. Hal ini disebabkan adanya isapan bayi pada payudara dilanjutkan melalui saraf ke kelenjar hipofise di otak yang mengeluarkan hormon oksitosin. Oksitosin selain bekerja untuk berkontraksi sehingga mempercepat proses involusi uteri. $^{3}$

Hasil penelitian yang dilakukan oleh Martini tahun 2012, tentang hubungan antara IMD dengan involusi pada ibu post partum di RSU Krian Husada Balangbendo Sidoarjo, menunjukan bahwa ada hubungan antara IMD dengan involusi ibu postpartum dengan nilai $p$ value $(0,000){ }^{4}$

\section{METODE}

Jenis penelitian untuk ini adalah observasional dengan pendekatan kohort. Pendekatan yang digunakan pada rancangan penelitian kohort adalah pendekatan waktu secara longitudinal atau time periode approach.

Jumlah subjek yang diteliti adalah 16 responden untuk setiap kelompok, dikarenakan terhadap kedua kelompok dilakukan IMD dengan perbedaan skala keberhasilan maka total sampel untuk kedua kelompok intervensi adalah 32 orang. Untuk menghindari drop out sampel di tambah 10\% sehingga sampel menjadi 18 orang (masing - masing kelompok) sehingga total sampel adalah 36 orang ibu post partum. Teknik pengambilan sampel secara consecutive sampling.

Kriteria inklusi penelitian sebagai berikut: Ibu dua jam post partum hari pertama yang mengalami persalinan normal, tidak menderita penyakit sistemik, kehamilan tunggal, ibu postpartum yang bayinya hidup, ibu tidak mengalami retensio plasenta, tidak dilakukan induksi persalinan, ibu dengan gravida $\leq 2$. Kriteria ekslusi dalam penelitian ini adalah: Ibu yang mengalami atonia uteri, adanya sisa plasenta setelah postpartum, ibu mengalami gangguan psikologis, bayi yang mengalami labiopalatoskizis, ibu yang mempunyai masalah dengan payudara.

\section{HASIL}

Hasil penelitian tentang hubungan Inisiasi Menyusu Dini (IMD) dengan kadar Oksitosin dan Involusi Uteri 2 Jam Post Partum, yang telah dilaksanakan di Klinik Bersalin Swasta Kabupaten Padang Pariaman yaitu : Klinik Bersalin Swasta Yetti Latief dan Klinik Bersalin Swasta Yulinda Laila sebanyak 36 orang subjek yang terdiri dari 18 orang berhasil IMD dan 18 orang tidak berhasil IMD dapat dilihat pada tabel dibawah ini:

Tabel 1. Distribusi kadar oksitosin pada ibu postpartum berdasarkan keberhasilan IMD di klinik bersalin swasta Kabupaten Padang Pariaman Tahun 2014

\begin{tabular}{ll}
\hline Kadar Oksitosin & Rerata \pm SD \\
\hline Berhasil IMD & $58,47 \pm 1.19 \mathrm{pg} / \mathrm{ml}$ \\
Tidak Berhasil IMD & $20.02 \pm 3.33 \mathrm{pg} / \mathrm{ml}$ \\
\hline
\end{tabular}

Berdasarkan Tabel 1, rerata kadar oksitosin ibu postpartum yang berhasil IMD $58,47 \mathrm{pg} / \mathrm{ml}$ dengan nilai maksimal $78,45 \mathrm{pg} / \mathrm{ml}$.

Tabel 2. Distribusi involusi uteri responden berdasarkan tinggi fundus uteri 2 Jam Post Partum berdasarkan keberhasilan IMD Di Klinik Bersalin Swasta Kabupaten Padang Pariaman

\begin{tabular}{ll}
\hline TFU & Mean \pm SD \\
\hline Berhasil IMD & $11.80 \pm 0,73 \mathrm{~cm}$ \\
Tidak Berhasil IMD & $12.85 \pm 0,38 \mathrm{~cm}$ \\
\hline
\end{tabular}


Berdasarkan Tabel 2, rerata tinggi fundus uteri ibu 2 jam postpartum yang berhasil IMD adalah 11.80 dengan panjang maksimal $13 \mathrm{~cm}$.

Tabel 3. Hubungan inisiasi menyusu dini dengan kadar oksitosin pada ibu postpartum di Klinik Bersalin Swasta Kabupaten Padang Pariaman Tahun 2014

\begin{tabular}{|c|c|c|}
\hline \multirow[t]{2}{*}{ IMD } & Kadar oksitosin & $\mathbf{P}$ \\
\hline & Rerata \pm SD & \\
\hline Berhasil & $58.47 \pm 1.19 \mathrm{pg} / \mathrm{ml}$ & \\
\hline Tidak Berhasil & $20.02 \pm 3.33 \mathrm{pg} / \mathrm{ml}$ & 0.001 \\
\hline
\end{tabular}

Hasil analisis hubungan IMD dengan kadar oksitosin pada ibu postpartum mempunyai rerata kadar oksitosin lebih tinggi pada kelompok yang berhasil IMD yaitu sebesar 58,47 pg/ml dengan standar deviasi $1,19 \mathrm{pg} / \mathrm{ml}$, sedangkan kadar oksitosin pada ibu postpartum yang tidak berhasil IMD 20,02 $\mathrm{pg} / \mathrm{ml}$ dengan standar deviasi $3,33 \mathrm{pg} / \mathrm{ml}$. Hasil uji statistik diperoleh nilai $p<0,05$ yang artinya ada hubungan yang bermakna antara Inisisasi Menyusu dini dengan kadar oksitosin pada ibu postpartum.

Tabel 4. Hubungan inisiasi menyusu dini dengan involusi uteri pada ibu 2 jam postpartum di Klinik Bersalin Swasta Kabupaten Padang Pariaman tahun 2014

\begin{tabular}{lll}
\hline IMD & $\begin{array}{l}\text { Involusi uteri } \\
\text { Mean } \pm \text { SD }\end{array}$ & p \\
& $11.80 \pm 0,73 \mathrm{~cm}$ & \\
\hline Berhasil & $12.85 \pm 0,38 \mathrm{~cm}$ & 0.001 \\
\hline
\end{tabular}

Hasil analisis hubungan IMD dengan Involusi Uteri pada ibu 2 jam postpartum mempunyai rerata involusi uteri lebih rendah pada kelompok yang berhasil IMD yaitu sebesar $11,80 \mathrm{~cm}$ dengan standar deviasi $0,073 \mathrm{~cm}$, sedangkan involusi uteri pada ibu 2 jam postpartum yang tidak berhasil IMD 12,85 cm dengan standar deviasi $0,38 \mathrm{~cm}$. Hasil uji statistik diperoleh nilai $p<0,05$ yang artinya ada hubungan yang bermakna antara inisiasi menyusu dini dengan involusi uteri pada ibu 2 jam postpartum.

\section{PEMBAHASAN}

Analisis hubungan IMD dengan Kadar oksitosin pada ibu postpartum mempunyai rerata kadar oksitosin lebih tinggi pada kelompok yang berhasil IMD yaitu sebesar $58,47 \mathrm{pg} / \mathrm{ml}$ dengan standar deviasi $1,19 \mathrm{pg} / \mathrm{ml}$, sedangkan kadar oksitosin pada ibu postpartum yang tidak berhasil IMD 20,02 pg/ml dengan standar deviasi 3,33 pg/ml. Hasil uji statistik diperoleh nilai $p<0,05$ yang artinya ada hubungan yang bermakna antara Inisiasi Menyusu dini dengan kadar oksitosin pada ibu postpartum.

Pada saat menyusui, terjadi kontak kulit ke kulit antara ibu dan bayi. Ketika kontak fisik antara ibu dan bayi tetap dipertahankan setelah bayi lahir, konsentrasi perifer oksitosin dalam sirkulasi maternal tampaknya menjadi tinggi dalam satu jam pertama dibanding sesaat sebelum lahir. ${ }^{5}$

Oksitosin merupakan zat yang dapat merangsang myometrium uterus sehingga dapat berkontraksi. Kontraksi uterus merupakan suatu proses yang kompleks dan terjadi karena adanya pertemuan aktin dan myosin. Pertemuan aktin dan myosin disebabkan karena adanya myocin light chain kinase (MLCK) dan dependent myosin ATP ase, proses ini dapat dipercepat oleh banyaknya ion kalsium yang masuk di dalam sel, sedangkan oksitosin merupakan suatu hormon yang memperbanyak masuknya ion kalsium ke dalam intra sel sehingga dengan adanya oksitosin akan memperkuat kontraksi uterus. $^{6,7}$

Pada tahun 2012, Rapaport et al mendapatkan hasil penelitian bahwasanya rerata kadar oksitosin pada kelompok yang tidak dilakukan IMD sebesar 27.6 $\pm 35.5 \mathrm{pg} / \mathrm{ml}$, sedangkan pada kelompok yang dilakukan IMD mempunyai rerata kadar oksitosin sebesar $80.1 \pm 42.0 \mathrm{pg} / \mathrm{ml}^{8}{ }^{8}$

Hasil analisis hubungan IMD dengan involusi uteri pada ibu 2 jam postpartum mempunyai rerata tinggi fundus uteri lebih rendah pada kelompok yang berhasil IMD yaitu sebesar $11,80 \mathrm{~cm}$ dengan standar deviasi $0,073 \mathrm{~cm}$, sedangkan involusi uteri pada ibu 2 jam postpartum yang tidak berhasil IMD $12,85 \mathrm{~cm}$ dengan standar deviasi $0,38 \mathrm{~cm}$. Hasil uji statistik diperoleh nilai $p<0,05$ yang artinya ada hubungan yang bermakna antara inisiasi menyusu dini dengan involusi uteri pada ibu 2 jam postpartum.

Bersamaan dengan pembentukan prolaktin oleh adenohipofise, rangsangan yang berasal dari isapan bayi ada yang dilanjutkan ke neurohipofise hipofise posterior yang kemudian dikeluarkan oksitosin 
melalui aliran darah, hormon oksitosin ini menuju uterus yang akan menimbulkan kontraksi pada uterus, sehingga terjadi involusi. Oksitosin yang sampai pada alveoli akan mempengaruhi sel mioepitelium.Kontraksi dari sel akan memeras air susu ibu keluar dari alveoli dan masuk ke sistem duktulus menuju duktus

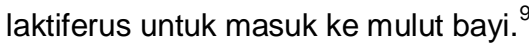

Berdasarkan hasil penelitian diatas juga dapat dianalisis sesuai dengan yang dikemukakan oleh Jordan pada tahun 2004 bahwasanya oksitosin merupakan suatu hormon yang dapat memperbanyak masuknya ion kalsium kedalam intrasel. Keluarnya hormon oksitosin akan memperkuat ikatan aktin dan myosin sehingga kontraksi uterus semakin kuat dan proses involusi uterus semakin bagus. $^{9}$

Pada tahun 2004 Jordan mengungkapkan bahwa oksitosin yang dihasilkan dari hiposis posterior pada nucleus paraventrikel dan nucleus supra optic. Saraf ini berjalan menuju neuro hipofise melalui tangkai hipofisis, dimana bagian akhir dari tangkai ini merupakan suatu bulatan yang mengandung banyak granula sekretrotik dan berada pada permukaan hipofise posterior dan bila ada rangsangan akan mensekresikan oksitosin. Sementara oksitosin akan bekerja menimbulkan kontraksi bila pada uterus telah ada reseptor oksitosin. ${ }^{9}$

Hormon oksitoksin yang dilepas dari kelenjar hipofisis memperkuat dan mengatur kontraksi uterus, mengompresi pembuluh darah dan membantu proses hemostasis. Kontraksi dan retraksi otot uterin akan mengurangi suplai darah ke uterus. Proses ini akan membantu mengurangi bekas luka implantasi plasenta serta mengurangi perdarahan. ${ }^{10}$

\section{KESIMPULAN}

Terdapat hubungan yang bermakna antara inisiasi menyusu dini dengan kadar oksitosin pada ibu postpartum. Terdapat hubungan yang bermakna antara inisiasi menyusu dini dengan involusi uteri pada ibu 2 jam postpartum

\section{UCAPAN TERIMA KASIH}

Terima kasih Kepada Klinik bersalin Yulinda Laila, SST dan Yetty Latif, SST yang telah bersedia menyediakan tempat penelitian.

\section{DAFTAR PUSTAKA}

1. Anderson $B$, Torvin Anderson $L$, Sorensen $T$. Methylergometrin during the early puerperium; a prospective randomized double blind study. Acta Obstetricia et Gynekology Scandinavica. 2000:15-9.

2. Roesli U. Inisiasi menyusu dini plus ASI eksklusif. Jakarta: Pustaka Bunda; 2008.

3. Departemen Kesehatan. Lactation management a handbook for midwifes and health provider in public health centres. Jakarta, Indonesia; 2008.

4. Martini. Hubungan inisiasi menyusu dini dengan tinggi fundus uteri 2 jam -7 hari post partum di wilayah kerja Puskesmas Suka Bumi Lampung Utara (tesis). Jakarta: Universitas Indonesial; 2012. Tersedia dari: URL: HYPERLINK http://www. reposiretori.UI.pdf

5. Nissen E, Lilia G, Widstrom A-M, Uvnas-Moberg. Different pattern of oxytocin, prolactin but not cortisol during breastfeeding in women delivered by Caesarian section or the vaginal route. Early Human Development. 2006;45:1003-18.

6. Sherwood. Fisiologi manusia dari sel ke sel (terjemahan). Jakarta: EGC; 2001.

7. Dasuki D, Rumekti D. Perbandingan efektivitas misoprostal per oral dengan oksitosin untuk prevensi pendarahan post partum. 2008. Tersedia dari: URL: HYPERLINK http://www.cnrl.net. publikasi.pdf.MPO

8. Rapaport $\mathrm{MH}$, Pamela S, Catherine BA Preliminary study of the effects of repeated massage on hypothalamic-pituitary-adrenal and immune function in healthy individuals: a study of mechanisms of action and dosage. The Journal Of Alternative And Complementary Medicine. Los Angeles: David Geffen School of Medicine at University of California; 2012. Tersedia dari: URL: HYPERLINK http://www.ncbi.nlm.nih.gov

9. Jordan S. Obat yang meningkatkan kontraksilitas uterus atau oksitosin. Dalam: Ester $M$, editor (penyunting). Farmakologi Kebidanan. Jakarta: EGC; 2004. HIm.70-5.

10. Bobak IM, Lowdermilk DL, Jensen. Keperawatan maternitas. Jakarta: EGC; 2005. 